\title{
Comparison of Male and Female Senior Secondary School Students' Learning Outcomes in Science in Katsina State, Nigeria
}

\author{
Dr. Olasehinde, Kayode John \\ Department of Science Education, Faculty of Science and Education, \\ Federal University, Dutsin-Ma, Katsina State \\ olasehindekayodej@gmail.com, kolasehinde@fudutsinma.edu.ng \\ Dr. Olatoye, Rafiu Ademola \\ Department of Science Education, Faculty of Science and Education, \\ Federal University, Dutsin-Ma, Katsina State. \\ kingdemola@yahoo.com, rolatoye@fudutsinma.edu.ng
}

Doi:10.5901/mjss.2014.v5n2p517

\begin{abstract}
The study compared male and female senior secondary school students' learning outcomes in science in Katsina State, Nigeria. The sample consisted of 204 students randomly selected from the three geopolitical zones of the state. Two instruments were used viz: (1) Attitude towards Science Questionnaire (ASQ); (2) Science Achievement Test (SAT). The respondents were asked to indicate their gender on the instruments. Data collected were analysed using t-test. The findings of the research showed that there were no significant difference between male and female students in overall science achievement $(t=-0.678, p>0.05)$, attitude to science $(t=0.387, p>0.05)$ and also biology, chemistry and physics achievements ( $t=0.502,1.501$ and $0.645, p>0.05$ respectively). It is therefore recommended among others that teachers should evoke instructional strategies that will sustain the gender equality in students' learning outcomes in science.
\end{abstract}

Keywords: Gender, students, learning outcomes, science

\section{Introduction}

The promotion of gender equality and empowerment of women is the Goal 3 of the eight Millennium Development Goals (MDGs) in which United Nations (UN) members have pledged to meet by the year 2015. Recent studies that attempted to evaluate the progress towards the MDGs pointed out the dismal progress made in bridging the gender divide in Nigeria (Ambe-Uva, Iwuchukwu \& Jibrin, 2008).

Gender refers to the social meanings associated with being a male or a female, including the construction of identities, expectations, behaviours and power relationships that derive from social interactions (Ambe-Uva, Iwuchukwu \& Jibrin 2008). Orji (2002) asserted that in Africa, especially in a traditional Nigerian setting female and male sex roles are seen as mutually exclusive. For instance, some professions like carpentry, engineering, woodwork, metalwork and automobile engineering technologies are still regarded in some quarters as no-go-area for women while nursing and catering profession are seen as exclusive areas for women.

Studies on the biological explanation of gaps in performance between male and female learners suggested that differences in brain structure, hormone production, and/or maturation rates may account for differentiated performance in school-related tasks. Studies further show that the parts of the brain responsible for processing verbal information and permitting the exchange of information between hemispheres were more highly developed in girls (Kimura, 2005). Girls also demonstrated earlier development in the brain regions responsible for impulse control, and, in general, matured earlier than boys (Viadero, 2006). However, the extent to which these biological differences manifested themselves in behavioural differences and their implications for learning was unknown.

Many reasons have been advanced for low participation of girls in science. Some studies reported that females are deficient in science because they lack analytical and visual-spatial skills that are needed for abstract reasoning in science (Acker \& Oatley, 1993). However, this argument has been proved wrong because emerging evidence shows that ability is not a determining factor in whether or not females would participate in science. Girls and boys are found to 
perform equally well if instructional context is fair and conducive (Campbell, Jolly, Hoey \& Perlman, 2002, Erinosho, 2008).

Some researchers reported that girls performed better, in some others boys do. Okwo and Otunba (2007) reported that gender influence achievement by $13.39 \%$ of the total influence factor. Aremu (1999) reported that boys are better than girls in Mathematics and other science subjects. Toh (1993) found that girls out performed boys in some other school subjects, while some other researchers found no difference in some cognitive tasks involving both boys and girls. Collis (1991) argued that secondary school policies requiring mathematics pre-requisites or co-requisites for work with computers always encourage greater participation of the male gender. If there is a single computing laboratory, it may be seen as a male territory. If computer resources are concentrated in the mathematics, science, and technology areas of the curriculum, many girls have no access to them.

Okwo and Otunba (2007) reported that boys performed better than girls in physics essay test. The joint influence of cognitive style and gender on the achievement of students in physics essay test was significant. Hedges and Nowell (1995) found no or slight gender differences in overall mathematics achievement, numerical ability, mathematics computation, concepts, and problem-solving.

While females used to lag behind males in a number of mathematics and science courses taken, in 2000, they now participated in the same or nearly the same number (Coley, 2001). Gender differences in science achievement on the National Assessment of Educational Progress (NAEP) and science courses taken between boys and girls in United States of America (USA) were minimal (Coley, 2001). Soboyejo (2007) reported no significant difference existed between male and female students' knowledge of communicable diseases.

Timetabling of subjects, assessment procedures, teacher expectations and behaviour, peer pressures, unequal funding, and stereotyped textbooks are among the long list of school factors thought to contribute to gender inequality. Teachers' attitudes and practices in particular have been singled out. A survey of secondary school teachers in Britain according to Pratt, 1985 found teachers of mathematics, physical sciences, and technical craft least in favour of equalopportunities initiatives. Spear (1985) reported large numbers of science teachers agreed with statements advocating traditional roles for women. The team working on the Girls into Science and Technology (GIST) project in the United Kingdom observed science teachers trying to attract boys' attention by suggesting that science was 'masculine', stressing its dangers (Whyte, 1985).

Raimi and Adeoye (2002) in their study on gender differences among college students as determinants of performance in integrated science found out that there is significant difference between male and female students in terms of their science achievement. However, the findings showed that males performed better than their female counterparts in integrated science achievement scores.

Also, Raimi and Adeoye's (2002) findings revealed that there is a significant difference between male and female students in term of their attitude towards integrated science in favour of male. Perhaps, this has been the reasons for males' better performance in integrated science achievement. This finding corroborates earlier findings of Raimi and Oduwaye (1997) which observed similar difference between males and females. This finding appears to confirm the fear of researchers such as Oyedeji (1996) that in African setting, science seems to wear a masculine label.

Some interventions to improve girls' attitudes toward and performance in science were effective while others were not. For example, teachers' use of an inquiry approach that combined efforts to raise students' interest and engagement, including appropriate laboratory techniques (Irohegbu, 1998), problem-solving (Adesoji,2008), scientific writing (Olagunju, 1996), mastery learning (Olasehinde, 2008) and further study reduced the gap between boys and girls. A physics intervention using an adapted physics curriculum led to increased achievement among boys and girls, but only under a condition involving part-time, single-sex instruction (Irohegbu, 1998). A chemistry approach that included visual representation of matter led to positive attitude and better performance by girls (Adesoji, 2008).

A study of gender gaps in mathematics achievement and attitude as measured by the National Assessment of Educational Progress, (NAEP, 2003) as reported in Lubienski, Lubienski and Crane (2009) showed that gaps in mathematics were generally small. Gender differences were greatest in the areas of measurement, number and operations and geometry. Gender differences tend to be concentrated in the upper-end of score distributions and most consistent for white, high Socio Economic Status (SES) students, although there were also gender differences for Hispanic students (McGraw, Lubienski, \& Strutchens, 2006). Study showed that mathematics achievement predicted later achievement in and attitudes toward science for both boys and girls (Ma \& Xu, 2004).

The study of gender differences among senior secondary school students is inconclusive. Therefore this study sought to compare male and female senior secondary school students' learning outcomes in science. Learning outcomes in this study focus on two variables. They are science achievement and attitude towards science. 


\section{Research Questions}

The following hypotheses will be tested at 0.05 level of significance:

1. Is there any significant difference between male and female students' achievement in science?

2. Is there any significant difference between male and female students' attitude to science?

3. Is there any significant difference between male and female students' achievement in (i) Biology (ii) Chemistry (iii) Physics?

\section{Methodology}

\subsection{Research Design}

The descriptive survey research design was employed to carry out this study. The aim of the researchers was to record, analyze and interpret the existing conditions or variables. The research is non-experimental and therefore variables were not manipulated. This makes descriptive survey research design suitable for this study. This design also accommodates generalization of findings of the study upon the target population from which only a representative sample was actually studied.

\subsection{Target Population and Sample}

The target population for the study comprised all the students in Senior Secondary School Two (SSII) in Katsina State, Nigeria. Katsina state is one of the 36 states in Nigeria. It has cultural and educational similarities with the six other states in the North-West geo-political zone of Nigeria. For the purpose of this study, Katsina state was divided into 3 zones namely: Daura, Funtua and Katsina. This is the existing political divisions in the state. A random sample of one Local Government Area (LGA) was selected from each zone. From each Local Government Area, a random sample of two public and two private schools were selected from each LGA and a total of 12 schools ( 6 public and 6 private schools) were selected from the entire state. From each school, twenty SSS 2 Science Students were randomly selected to participate in the study except private schools in Daura and Katsina zones where intact classes were used because the researchers could not get 20 students in each class. Thus a total of 204 students participated in the study. The average age of the students is 17 years.

\subsection{Instrumentation}

Two instruments were used to collect data for this study. They are:

i. Attitude towards Science Questionnaire (ASQ)

ii. Science Achievement Test (SAT)

ASQ was designed by the researchers. This questionnaire has 12 items with a four-point Likert-type scale of 'Strongly Agree', 'Agree', 'Disagree' and 'Strongly Disagree'. The respondents were asked to indicate their feelings to each statement/item by ticking any of the four possible responses on the scale. The items one the instruments cover different aspects of the variables being considered. Respondents were asked to indicate their gender on the questionnaires.

SAT is a 30-item achievement test that covers the three core subjects in science namely biology, chemistry and physics. Ten items were drawn from each of these subject areas.

Examples of items on ASQ:

1. I just like to listen to news of latest scientific discoveries.

2. I like to work in the laboratories.

3. I discuss science among my friends.

Examples of items on SAT:

1. A group of closely related organisms capable of interbreeding to produce fertile offspring are known as members of (a) kingdom (b) class (c) family (d) species

2. How many orbital is in the d-sub shell? (a) 1 (b) 3 (c) 5 (d) 7 .

3. The derived unit of pressure can be expressed as: (a) Kgms ${ }^{-2}$ (b) $\mathrm{Kgms}^{-2}$ (c) $\mathrm{Kgm}^{-2} \mathrm{~s}^{-2}$ (d) $\mathrm{Kgm}^{-1} \mathrm{~s}^{2}$

The content validity of the questionnaire and the achievement tests was ensured through experts' suggestions and 
guidance. Experts in questionnaire construction helped in critiquing the items. All the achievement items were selected from already standardised items produced by the West African Examinations Council. The items selected were only on the topics covered in all the schools selected for the study. The test retest reliability yielded .827 and .862 coefficients for ASQ and SAT respectively.

\subsection{Method of Data Analysis}

The data collected were analysed using the Statistical Package for Social Sciences (SPSS) version 17.0. All the research questions were answered using t-test.

\section{Results}

\subsection{Research Question 1}

Is there any significant difference between male and female students' achievement in science?

Table 1: Comparison of Male and Female Students' Science Achievement

\begin{tabular}{|c|c|c|c|c|c|c|c|c|c|}
\hline Variable & Gender & $\mathrm{N}$ & Mean & Std Dev & Std Error & df & t & P & Remark \\
\hline Science Achievement & Male & 119 & 7.0840 & 3.05203 & .27978 & \multirow{2}{*}{202} & -.678 & .498 & NS \\
& Female & 85 & 7.3882 & 3.30258 & .35821 & & & & \\
\hline
\end{tabular}

NS= Not significant $(p>0.05)$.

Table 1 indicates that there is no significant difference between male and female students in science achievement $(\mathrm{t}=$ $0.678, p>0.05$ ). However, the science achievement mean score of female students (Mean= 7.39) is higher than the science achievement mean score of their male counterparts (Mean $=7.08$ ). This reveals that though there is no significant difference in the mean scores of male and female students in science achievement, female students performed better than the male counterparts.

\subsection{Research Question 2}

Is there any significant difference between male and female students' attitude to science?

Table 2: Comparison of Male and Female Students' Attitude to Science

\begin{tabular}{|c|c|c|c|c|c|c|c|c|c|}
\hline Variable & Gender & $\mathrm{N}$ & Mean & Std Dev & Std Error & df & t & P & Remark \\
\hline \multirow{2}{*}{ Attitude to Science } & Male & 119 & 38.1849 & 4.53978 & .41616 & 202 & -.387 & .699 & NS \\
& Female & 85 & $38 . .4588$ & 5.54323 & .60125 & 2 & & \\
\hline
\end{tabular}

NS= Not significant $(p>0.05)$

Table 2 shows that there is no significant difference between male and female students attitude to science $(t=0.387$, $p>0.05$ ). The results further reveals that female students have a mean score of 38.4 which is higher than the male students mean score of 38.18. This indicates that the female students have more positive attitude towards science than the male students. However, the difference in the mean scores is not significant.

\subsection{Research Question 3}

Is there any significant difference between male and female students' achievement in (i) Biology (ii) Chemistry (iii) Physics?

Table 3: Comparison of Male and Female Students' Achievement in Biology, Chemistry and Physics

\begin{tabular}{|c|c|c|c|c|c|c|c|c|c|}
\hline Variables & Gender & $\mathrm{N}$ & Mean & Std Dev & Std Err & df & t & P & Remark \\
\hline Biology Achievement & Male & 119 & 2.5966 & 1.62772 & .13252 & 202 & .502 & .616 & NS \\
\hline
\end{tabular}




\begin{tabular}{|l|c|c|c|c|c|c|c|c|c|}
\hline & Female & 85 & 2.4824 & 1.57065 & 18952 & & & & \\
\hline \multirow{2}{*}{ Chemistry Achievement } & Male & 119 & 2.1765 & 1.4356 & .13163 & \multirow{2}{*}{202} & -1.501 & \multirow{2}{*}{.135} & \multirow{2}{*}{ NS } \\
& Female & 85 & 2.4941 & 1.56314 & .16955 & & & \\
\hline \multirow{2}{*}{ Science Achievement } & Male & 119 & 2.3109 & 1.45990 & .13383 & \multirow{2}{*}{202} & -.462 & .645 & \multirow{2}{*}{ NS } \\
& Female & 85 & 2.4118 & 1.64240 & .17814 & & & \\
\end{tabular}

NS= Not significant $(p>0.05)$

Table 3 shows that there is no significant difference between male and female students' achievement in, Biology, Chemistry and Physics ( $t=0.502,1.501$ and .645 respectively, $p>0.05)$. Though the maximum obtainable score in each of the three subjects is 10, yet the average performance is not up to 3 in any of the subjects. This implies that the percentage mean is not up to $30 \%$ in each of the subjects.

\section{Discussion}

The result reveals that there is no significant difference between male and female students in science achievement. This negates the finding of (Aremu, 1999; Toh, 1993 Okwo and Otunba, 2007; Raimi and Adeoye, 2002) that asserted significant difference between male and female students in science achievement. The results uphold Olagunju (1998) reported that there was no significant difference between male and female students in science achievement. However the mean score of female students is higher than that of male students. This shows that the female students performed better than the male students in science achievement. The difference between the two mean scores of male and female students is marginal. The mean achievement scores of both male and female students are very low in biology, chemistry and physics. This may be attributed to the students', parents' environmental or teacher factors. The relatively poor performance has no gender inclination.

The findings further show that there is no difference between male and female students' attitude to science. This contradicts Adesoji (2008) that reported significant difference between male and female students in attitude to science. Soboyejo, (2007) reported that there is significant difference between male and female students' attitude to science but the male had a little more positive attitude than the female students. In this study, the male students have higher positive attitude towards science than the male students, though the difference is not significant.

The finding also shows that the male students and female students have no significant difference in biology, chemistry and physics achievements which supports Irheogbu (1998) study. However the male students have slightly higher mean score than the female students in biology achievement. In chemistry and physics achievements, the mean scores of female students are slightly higher than the male students. Students did not show good performance biology, chemistry and physics, the achievement mean scores are below average.

Olatoye and Agbatogun (2009), Olatoye (2009a, 2009b) reported that there is no gender difference in science. Even in an experimental study involving project-based and demonstration methods as treatment, Olatoye and Adekoya (2010) reported that there was no significant interaction effect of treatment and gender on students' achievement. This implies that both male and female students are at the same level of achievement in science.

Olatoye (2002) opined that science education lays foundation for work in science-related fields by acquainting learners with certain knowledge and skills. With the very low achievement students in science reported in the study, there is need to look outside the factors considered in this study. According to Olatoye ((2009a, 2009b) factors such as test anxiety, motivation for examinations, study habit and self-concept have significant influence on students' achievement in science.

\section{Conclusion}

The findings in this study show that gender disparity reported in many previous studies is not the case here. There is no significant difference between male and female students' general achievement and attitude towards science. There is also no gender difference in student science achievement in each of the three science subjects namely biology, chemistry and physics. The findings from this study are contrary to findings from many previous studies that reported gender difference in science achievement and attitude and attitude toward science in favour of the male gender. The findings from this study however support the fact that gender gap between male and female students is narrowing down. This can be as a result of emphasis and consciousness by parents and teachers that male and female students should benefit equally from teaching. However, the very poor performance of students in science should be looked into. In this study students average achievement in science is below 30 percent. 


\section{Recommendations}

It is therefore recommended that teachers should evoke strategies that will sustain the gender equality. The number of female students is lower than male students in science subjects. Hence more female friendly science programmes should be organised to woo female students to science subjects. Role models should be made available to both genders. Gender friendly textbooks should be written by science authors.

\section{References}

Acker, S. \& Oatley, K. (1993). Gender Issue in Education for Science and Technology: Current Situation and Prospects for Change. Canadian Journal of Education. 18(3), 255-272.

Adesoji, F. A. (2008).Managing Students' Attitude Towards Science through Problem-Solving Instructional Strategy. Anthropologist, 10(1), 21-24.

Akinsola, M. K. (1998). Comparative Effects of Mastery Learning and Enhanced Mastery Learning Strategies on Students Achievement and Self-Concepts in Mathematics. Unpublished Ph.D Thesis, Teacher Education Department. University of Ibadan, Nigeria.

Ambe-Uva T. N., Iwuchukwu, O. \& Jibrin L. J. (2008). Gender Analysis in National Open University of Nigeria (NOUN): Implication and Policy Issues in Bridging the Divide. Journal of Applied Science Research 4 (7), 814-825

Aremu, S. A. (1999). Games and Primary School Pupils' Achievement in Some Aspect Of Geometry. Unpublished Ph.D Thesis, Department of Teacher Education, University of Ibadan, Ibadan.

Campbell, P.E. Jolley, L. Hoey, L. \& Perlman, L. (2002). Upping the Numbers: Using Research-based Decision-making to Increase the Diversity of Quantitative Disciplines. Newton, MA; Education Development Center, Inc.

Collis, B. (1991). Adolescent Females and Computer: Real and Perceived Barriers. In: Gaskell, J. and Mc Laren (Eds) Women and Education: A Canadian Perspective Calgary: Detselig, 2, 147-161.

Coley, R. (2001). Differences in the Gender Gap: Comparisons Across racial/Ethnic Groups in Education and Work (Policy Information Report). Educational Testing Service. Princeton, NJ:

Erinosho, S. Y. (2008). Teaching in Science in Senior Secondary Schools: A Methodology Handbook. Lagos: African Cultural Institute.

Hedges, L, \& Nowell, A. (1995). Sex Differences in Mental Test Scores, Variability, and Numbers of High-Scoring Individuals. Science, 269, 41-45.

Irohegbu, T. O. (1998). Problem-based Learning, Numerical Ability and Gender as Determinants Skill as Senior Secondary Physics in Ibadan. Unpublished Ph.D thesis. Teacher Education Department. University of Ibadan.

Kimura, D. (2005). Sex Differences in the Brain. Scientific American, Battle of the Sexes. (Exclusive Online Issue 20).

Ma, X., \& Xu, J. (2004,). Determining the Causal Ordering between Attitude Toward Mathematics and Achievement in Mathematics. American Journal of Education, 110, 256-280.

McGraw, R., Lubienski, S. T., \& Strutchens, M. E. (2006). A Closer Look at Gender in NAEP Mathematics Achievement and Affect Data: Intersections with Achievement, Race/Ethnicity, and Socioeconomic Status. Journal of Research in Mathematics Education, $37(2), 129-150$

Okwo, F. A. and Otunba, S (2007). Influence of Gender and Cognitive Styles in Science Achievement in Physics Essay Test. Journal of Science Teachers Association of Nigeria 42 (1\&2), 85-88.

Olasehinde, K. J. (2008). Effect of School of Location On Student Cognitive Achievement n population Education Concepts in Biology. Sahel Analyst. Journal of the Faculty of of Social and Management Sciences 10 (1), 43-48

Olagunju, A M (1996).The Attitude to the Use of Computer for Teaching and Learning: Implication for Science Education. Nigerian Journal of Computer Literacy 1:1.

Olatoye, R.A, (2002). A Causal Model of School Factors as Determinants of Science Achievement in Lagos State Secondary Schools. An Unpublished PhD Thesis, University of Ibadan, Nigeria.

Olatoye, R A. (2009a). Study habit, Self-concept and Science Achievement of Public and Private Junior Secondary School Students in Ogun State, Nigeria. African Research Review, 13, (4),

Olatoye, R. A. (2009b) Students' Test Anxiety. Motivation for examinations and science achievement in junior secondary schools in ogun state, Nigeria. International Journal of Psychology and Counselling,1 (10), 194-198.

Olatoye R. A. \& Adekoya Y. M. (2010). Effect of Project-based, Demonstration and Lecture Teaching Strategies on Senior Secondary School students Achievement in an aspect of Agriculture Science. International Journal of Educational Research and Technology, 1 (1), 19-29.

Olatoye, R A. \& Agbatogun A. A.(2009). Parental involvement as correlates of pupils' achievement in mathematics and science in Ogun state, Nigeria. Educational Research and Review, 4 (10), 457-464.

Orji, A. B. C. (2002). Gender Imbalance in Science and Technology in Basic Human Resource Development in Africa: Causes and Remedies. 43rd Annual Conference Proceeding of Science Teachers' Association of Nigeria. 114-116

Oyedeji, A.O. (1996). Assessing Gender Factor in Some Science and Mathematics Tests in Nigeria. Journal of Education Research 8 (1), 45-53.

Pratt, J. (1985). The Attitude of teachers: In: Whyte, J. Dean, L. and Cruickshank, M. (Eds) . Girls Friendly Schooling, London: Methuen. Raimi, S. A. \& Adeoye, F. A. (2002).Gender Difference among College Students as Determinant of Performance in Integrated Science. 
African Journal of Educational Research, 8 (1\&2), 41-49.

Raimi, S. A. \& Oduwaye, J. O. M. (1997). College Students' Attitude towards Integrated Science as a Predictor of Achievement in the Subject. Journal of Science Education 2 (2), 10-17.

Soboyejo, A. N. A. (2007). Academic Discipline and Gender Difference in Secondary School Students' Knowledge and Practice on Communicable Diseases. 50th Annual Proceeding of Science Teachers' Association Nigeria, 196-203.

Spear, M. (1985). Teachers' Attitude, Girls and Technology. In: Whyte, J. Dean, L. and Cruickshank, M. (Eds) Girls Friendly Schooling, London: Methuen.

Toh, K.A. (1993). Gender and Practical Tasks. Science Education Research 35, 225-265.

Viadero, D. (2006). Concern Over Gender Gaps Shifting to Boys. Education Week, 25 (27), 16-17.

Whyte, J. (1985). Girl Friendly Science and Girl Friendly Schooling. In: Whyte, J. Dean, L. and Cruickshank, M. (Eds). Girls Friendly Schooling, London: Methuen, 77-92. 
